\title{
SUBSTANSI ANTIBAKTERI JAMUR ENDOFIT PADA LAMUN ASAL PERAIRAN TONGKAINA
}

\section{(Antibacterial Substance of Endophytic Fungus on Seagrass from Tongkaina Waters)}

\author{
Galih E. H. Prasetyo' ${ }^{*}$, Remy E. P. Mangindaan', Robert A. Bara1
}

1. Program Studi IImu Kelautan Fakultas Perikanan dan IImu Kelautan Universitas Sam Ratulangi, Manado.

*e-mail: galihhariprasetyo@gmail.com

Seagrass is a part of Phanerogamae, commonly has a symbiotic relationship with microbial endophytes. The types of microbes those have ability to produce bioactive compounds with potentially exploited for medical, agriculture and industrial purposes. Antibacterial testing using the modified Kirby-Bauer method. The fungi show a strong antibiotic activity which cultivated statically and Staphylococcus aureus was induced in rice medium for 10 days. The purpose of inducing bacteria to the culture is to stimulate a strong antibiotic activity through Silence Biosynthesis Pathway. Fungal isolates were macerated with $96 \%$ of ethanol for 24 hours. Partition process was performed by adding solvents (ethyl acetate, n-hexane, ethanol and water) to get $\mathrm{n}$-hexane, ethanol and water fractions. All fractions were tested their activity against clinical isolates bacteria $S$. aureus and Escherichia coli. Ten fungal endophytes were isolated from seagrass Thalassia hemprichii and Enhalus acoroides. Two isolates derived from the leaf of both seagrass specimens (E.D.1 and Th.D.1) showed strong antibacterial activity against $S$. aureus only. Antibacterial activity test of each fraction both active isolates show in water and ethanol fractions. This indicates the active antibacterial compounds of both endophytic fungi have semi-polar and polar characteristics. However, bacterial induction has no effect on their antibacterial activity.

Keywords : Endophytic fungi, Thalassia hemprichii, Enhalus acoroides, antibacterial activity Staphylococcus aureus and Escherichia coli.

Lamun merupakan tanaman tingkat tinggi yang mempunyai hubungan simbiosis dengan mikroba jamur endofit. Mikroba endofit ini mempunyai kemampuan untuk memproduksi senyawa-senyawa bioaktif dengan potensi yang besar untuk dieksploitasi dan menghasilkan yang bermanfaat di bidang medis, pertanian, dan industri. Isolasi jamur dilakukan mengacu pada penelitian Bara et al (2013). Pengujian antibakteri dilakukan berdasarkan metode KirbyBauer yang dimodifikasi. Jamur memperlihatkan aktivitas antibiotik yang kuat dikultivasi statis dan di induksikan bakteri $S$. aureus dalam media nasi selama 10 hari. Tujuan pemberian bakteri pada kultur yaitu untuk memicu adanya aktivitas antibiotik yang lebih kuat melalui jalur biosintesis senyap (Silence Biosintethic Pathway) pada jamur tersebut. Isolat jamur di maserasi dengan menambahkan etanol $96 \%$ selama 24 jam. Proses partisi dengan menambahkan pelarut (etil asetat, n-heksan, etanol dan air) untuk memperoleh fraksi n-heksan, etanol dan air. Tiap fraksi diuji kembali aktivitas antibiotiknya pada bakteri S. aureus dan Escherichia coli. Hasil penelitian ini diperoleh sepuluh isolat jamur dari lamun $T$. hemprichii dan $E$. acoroides. Dua isolat daun (E.D.1 dan Th.D.1) menunjukkan aktivitas yang kuat terhadap bakteri $S$. aureus. Pengujian aktivitas antibakteri tiap fraksi kedua isolat jamur memperlihatkan fraksi air dan etanol yang menunjukkan aktivitas penghambat. Hal ini menunjukkan bahwa senyawa aktif antibakteri kedua jamur endofit berisfat semi polar dan polar. Induksi bakteri tidak memberikan pengaruh terhadap aktivitas antibakteri.

Kata Kunci : jamur endofit, Thalassia hemprichii, Enhalus acoroides, aktivitas antibakteri Staphylococcus aureus dan Escherichia coli. 


\section{PENDAHULUAN}

Sebagai negara kepulauan, 73 persen wilayah Indonesia merupakan wilayah perairan yang sangat kaya akan sumber daya laut. Menurut ditjen Pengelolaan Ruang Laut KKP secara keseluruhan jumlah pulau yang terdapat di Indonesia sekitar 14.572 pulau yang telah dibakukan namanya. Oleh karena itu tidak mengherankan bila perairan laut Indonesia kaya akan berbagai organisme laut baik flora maupun fauna, yang salah satunya digunakan sebagai sumber obatobatan. Lebih dari 10.000 senyawa baru telah diisolasi dari bakteri, fungi, mikroalga atau makroalga, lamun, spons, karang lunak, moluska, echinodermata dan ascidian (Fusetani, 2000; Nontji, 2005).

Resistensi antibiotik merupakan permasalahan penting di bidang kesehatan. Berbagai jenis kuman patogen berkembang menjadi resisten terhadap satu atau beberapa jenis antibiotik. Hal ini yang menyebakan para peneliti selalu berusaha untuk mencari bahan-bahan antibiotik baru dari organisme laut salah satunya Lamun.

Lamun merupakan tanaman tingkat tinggi mempunyai hubungan simbiosis dengan mikroba baik bakteri dan jamur, simbiosis ini dapat bersifat epifit atau endofit. Mikroba endofit mempunyai kemampuan untuk memproduksi senyawa-senyawa bioaktif yang serupa dengan senyawa bioaktif yang diproduksi inangnya. Organisme endofitik memiliki potensi yang besar untuk dieksploitasi dan menghasilkan senyawa-senyawa alami baru yang bermanfaat di bidang medis, pertanian, dan industri. Produk bahan alam dari organisme endofit mempunyai kemampuan menghambat dan juga membunuh beragam mikroorganisme patogen seperti bakteri, jamur, virus dan protozoa (Nuriah, 2014; Strobel et al, 2003; Bara et al. 2013).
Adapun tujuan yang dilakukan dalam penelitian ini adalah mengisolasi jamur endofit yang terdapat pada akar, batang dan daun lamun $T$. hemprichii dan $E$. acoroides yang tumbuh di perairan Tongkaina. Menentukan aktivitas jamur endofit yang terdapat pada lamun $T$. hemprichii dan $E$. acoroides terhadap bakteri uji $S$. aureus dan E. coli. Memicu produksi senyawa antibakteri pada jamur yang diteliti melalui Jalur Biosintesis Senyap (Silence Biosyntethic Pathway) dengan teknik ko-kultivasi. Menentukan kepolaran senyawa aktif antibakteri pada setiap ekstrak isolat jamur endofit $T$. hemprichii dan E. acoroides.

\section{METODE PENELITIAN}

\section{Pengambilan sampel}

Sampel lamun diambil di Pantai Tongkaina, Kecamatan Bunaken, Kota Manado. Proses pengambilan sampel menggunakan alat snorkeling pada kedalaman 0.5-1 meter. Lalu sampel dimasukkan ke dalam plastik sampel dan diberi label, kemudian sampel dibawa ke Laboratorium Biologi Molekuler dan Farmasetika Laut, Fakultas Perikanan dan IImu Kelautan, UNSRAT. Sampel lamun diidentifikasi dengan cara mengamati morfologi lamun mulai dari bentuk daun, ukuran, dan akar. Hasil pengamatan morfologi lamun kemudian di lihat pada situs "www.seagrasswatch.org".

Alat-alat yang digunakan dalam keadaan bersih dan steril. Media yang digunakan adalah media agar singkong (cassava agar), Media Nasi, Media Nutrien Agar dan Media kombinasi yang digunakan sebagai media pengujian aktivitas antibakteridari jamur endofit terhadap bakteri uji.

\section{Isolasi jamur endofit}

Isolasi jamur endofit mengacu pada penelitian Bara et al (2013). Sampel daun, batang dan akar lamun Thalassia hemprichii dan Enhalus 
acoroides yang telah diambil dipotong kira-kira $5 \mathrm{~cm}$ dan dicelup dalam larutan etanol $70 \%$ selama 30 detik untuk mengindari kontaminasi silang mikroba epifit. Setelah itu dipotongpotong dengan ukuran sekitar $1 \mathrm{~cm}$ menggunakan gunting steril. Potongan ini selanjutnya ditanam pada media agar singkong (Cassava agar) di dalam cawan petri. Penambahan kloramfenikol $0.2 \mathrm{~g} / \mathrm{L}$ ke dalam media agar untuk mencegah pertumbuhan bakteri endofit. Tiap cawan berisi 4 potongan sampel, lalu ditutup kemudian di simpan pada suhu kamar $\left(25^{\circ} \mathrm{C}\right)$. Setelah 2-3 hari terlihat pertumbuhan jamur di sekitar sampel yang telah diletakkan di media agar.

Miselia jamur yang tumbuh pada media agar singkong kemudian secara bertahap diisolasi satu-persatu dengan menggunakan scalpel steril dan dipindahkan ke media singkong steril pada cawan petri lainnya. Jamur endofit yang telah tumbuh selanjutnya dinokulasi ke dalam media agar baru tanpa pemberian antibiotik.

\section{Skrining Aktivitas Antibiotik dari Jamur Endofit}

Miselia jamur endofit yang sudah tumbuh diambil sebagian dengan menggunakan sedotan steril dan dipindahkan ke media kombinasi yang sudah diolesi bakteri uji ( $S$. aureus dan $E$. coli). Selanjutnya petri yang berisi jamur endofit diinkubasi dalam suhu $25^{\circ} \mathrm{C}$ selama 1-2 x 24 hari. Setelah itu diamati aktivitas antibiotik terhadap $S$. aureus dan E. coli.

\section{Kultivasi dan Ekstraksi Jamur pada Media Nasi}

Kultur jamur pada media nasi secara statik selama 10 hari pada suhu ruang. Setelah pertumbuhan misilia jamur endofit mencapai bagian dasar dari labu erlenmeyer dilakukan ekstraksi. Proses ini dilakukan dengan menambahkan etanol 95\% sampai semua nasi terendam lalu diaduk dengan shaker selama selama 24 jam. Rendaman selanjutnya disaring kemudian di evaporasi menggunakan Rotary vacuum evaporator pada suhu $40^{\circ} \mathrm{C}$.

\section{Partisi}

Partisi dari ekstrak kasar jamur dilakukan pada ekstrak yang menunjukan aktivitas antibakteri yang kuat. Prosedur kerja partisi dilakukan dengan menambahkan air dan etil asetat pada ekstrak kemudian larutan yang terbentuk dimasukkan ke dalam corong pisah (separotory funnel) lalu dikocok dan didiamkan selama 10 menit, sehingga akan terlihat 2 lapisan yaitu fraksi air dan fraksi etil asetat. fraksi etil asetat kemudian dievaporasi kemudian difraksinasi kembali dengan n-heksan dan etanol $70 \%$ (perbandingan 1:1) dalam corong pisah kemudian dikocok serta didiamkan lagi selama 10 menit sehingga nampak adanya 2 lapisan yaitu fraksi heksan dan fraksi etanol. Kedua fraksi kemudian dievaporasi untuk menguapkan pelarut. Ketiga fraksi (fraksi n-heksan, etanol dan air) diuji aktivitasnya kembali untuk mengetahui lokasi senyawa aktif yang berada.

\section{HASIL DAN PEMBAHASAN}

\section{Identifikasi lamun}

Identifikasi morfologi didasarkan pada panduan yang digunakan, diperoleh dua jenis lamun yaitu: $T$. hemprichii dan E. acoroides yang tersaji pada Gambar 1.

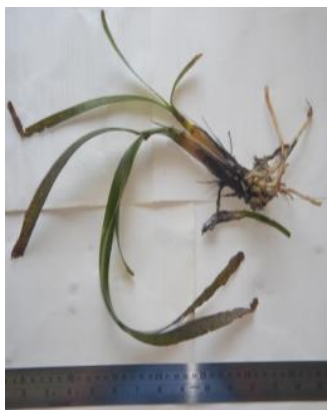

E. acoroides

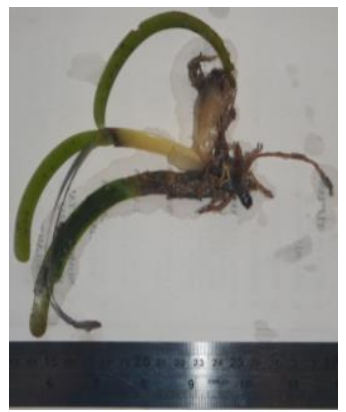

T. hemprichii
Gambar 1. Jenis-jenis sampel lamun 


\section{Jamur yang di isolasi}

Hasil pembiakan jamur endofit yang berasal dari akar, batang dan daun lamun E. acoroides dan T. hemprichii yang diambil dari lokasi pantai Tongkaina menghasilkan 10 spesies jamur endofit. Pada lamun E. acoroides diperoleh 5 isolat jamur diantaranya satu dari isolat akar dan empat dari isolat daun, sedangkan lamun $T$. hemprichii diperoleh 5 isolat jamur diantaranya dua dari isolat akar, dua dari isolat batang dan satu dari isolat daun.

Pada bagian tumbuhan yang berbeda dapat diisolasi jamur endofit yang berfariasi/berbeda bentuk koloni, dan warna miselia. Isolat jamur dari bagian akar $T$. hemprichii memiliki bentuk miselia berwarna cokelat tua dan putih seperti kapas. Sedangkan dari bagian batang isolat jamur memiliki miselia dengan warna putih seperti benang dan coklat muda.

Pengujian awal isolat jamur pada bakteri $S$. aureus dan $E$. coli
Hasil pengujian dari 10 isolat jamur endofit terhadap bakteri $S$. aureus dan $E$. coli, menunjukkan adanya zona hambat pada isolat jamur E.D.1, dan Th.D.1 daun dari kedua jenis lamun. Isolat jamus asal batang dan akar kedua lamun tidak memperlihatkan adanya daya hambat terhadap kedua bakteri uji. Hal ini menunjukkan jamur endofit yang diisolasi dari daun mampu menghasilkan senyawa-senyawa aktif antibakteri. Hasil pengamatan aktivitas antibakteri pada isolat jamur endofit selama 1x24 jam pengamatan tersaji pada Tabel 1.

Adanya aktivitas antibiotik hanya pada bakteri $S$. aureus dikarenakan bakteri ini termasuk dalam bakteri gram positif. Hal ini dikarenakan perbedaan fisiologi antara bakteri gram negatif dengan bakteri gram positif. Dimana bakteri gram positif hanya memiliki satu membran plasma dan dinding sel yang tebal sedangkan bakteri gran negatif memiliki dua membran plasma dan dinding sel yang tipis.

Tabel 1. Uji aktivitas antibakteri jamur endofit T. hemprichii dan E. acoroides terhadap bakteri S.aureus dan E.coli

\begin{tabular}{|c|c|c|c|}
\hline No & Kode isolat & Staphylococcus aureus & Eschercia coll \\
\hline \multicolumn{4}{|l|}{ Isolat akar } \\
\hline 1 & Th.A.1 & - & - \\
\hline 2 & Th.A.2 & - & - \\
\hline 3 & E.A. 1 & - & - \\
\hline \multicolumn{4}{|l|}{ Isolat batang } \\
\hline 4 & Th.B.1 & - & - \\
\hline 5 & Th.B.2 & - & - \\
\hline \multicolumn{4}{|l|}{ Isolat daun } \\
\hline 6 & E.D.1 & + & - \\
\hline 7 & E.D.2 & - & - \\
\hline 8 & E.D.3 & - & - \\
\hline 9 & E.D.4 & - & - \\
\hline 10 & Th.D.1 & + & - \\
\hline
\end{tabular}




\section{Kultivasi dan ekstraksi dari jamur endofit pada media nasi}

Dari pengujian awal antibakteri 2 isolat yang terdapat pada bagian daun Th.D.1, E.D.1 dikultur pada media nasi untuk mendapatkan biomassa ekstrak jamur yang lebih banyak untuk diteliti lebih lanjut. Isolat jamur daun (E.D.1 dan Th.D.1) ditumbuhkan di dalam media nasi kemudian diinkubasi statik pada suhu kamar selama 10 hari. Induksi bakteri dilakukan pada isolat E.D.1 (E.D.1+S.a) dan Th.D.1 (Th.D.1+S.a).

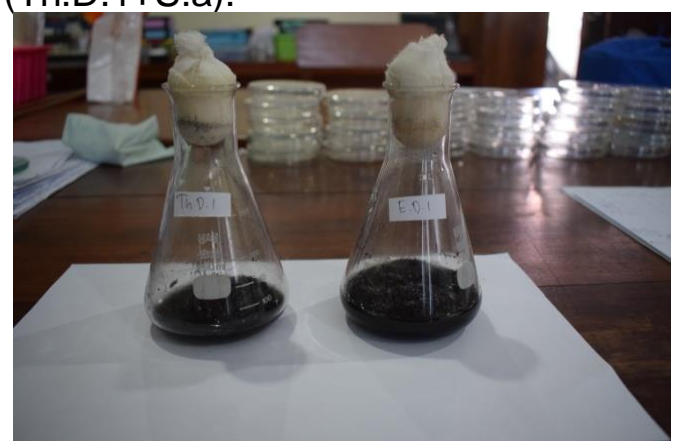

Gambar 2. Kultivasi jamur endofit pada media nasi

Tujuan pemberian bakteri pada kultur yaitu memicu jamur untuk menghasilkan senyawa tertentu melalui jalur biosintesis senyap (Silent Biosynthetic Pathway) pada jamur tersebut. Proses inkubasi dihentikan dengan cara maserasi dengan menambahkan etanol $96 \%$ ke dalam kultur selama 3×24 jam. Ekstrak kemudian disaring, filtrat yang diperoleh dievaporasi untuk menguapkan pelarut. Keempaat ekstrak kemudian diujikan kembali aktivitas antibakterinya.

\section{Pengujian aktivitas antibakteri dari ekstrak}

Setelah diinkubasi pada temperatur $37^{\circ} \mathrm{C}$ dalam inkubator selama 1x24 jam, keempat ekstrak menunjukan aktivitas antibakteri terhadap bakteri $S$. aureus dan E. coli dengan terlihatnya zona hambat di sekitar keempat ekstrak isolat jamur endofit dan kontrol positif terhadap kedua bakteri uji yang tersaji pada Gambar 3. Hasil pengukuran diameter zona hambat keempat isolat jamur endofit tersaji dalam Tabel 2.

- Pengamatan memperlihatkan semua ekstrak menunjukan aktivitas kepada dua bakteri uji. Hasil pengukuran diameter zona hambat menunjukkan bahwa ekstrak isolat jamur endofit Th.D.1 memiliki nilai ratarata zona hambat lebih besar dibandingkan dengan jamur endofit Th.D.1 yang diinduksi bakteri $S$. aureus.

Nilai pengukuran zona hambat yang diperoleh dari isolat jamur Th.D.1 adalah $26 \mathrm{~mm}$ terhadap bakteri $E$. coli dan 23.7 terdapap bakteri $S$. aureus, sedangkan isolat jamur Th.D.1+S.a memiliki nilai zona hambat $18 \mathrm{~mm}$ untuk bakteri $E$. coli dan 18.7 untuk bakteri $S$. aureus. Begitu juga dengan isolate jamur endofit E.D.1 memiliki diameter zona hambat lebih besar dibandingkan dengan E.D1.+ Sa. Hal ini menunjukkan bahwa induksi bakteri S. aureus pada isolat Th.D.1 dan E.D.1 tidak memberikan pengaruh besar pada kedua jamur uji.

Hal ini sesuai dengan penelitian Sihombing et al (2017) dimana jamur simbion dari spons $P$. Melobesioides dan Plakortis sp. dan Nawea et al (2017) jamur simbion yang diperoleh dari Sonneratia alba yang sama-sama di induksi pada bakteri $S$. aureus tidak meningkatkan aktivitas antibakteri. Berbeda dengan penelitian Ola et al (2013) yang mengungkap kultivasi bersama jamur endofit Fusarium tricintum dengan bakteri Bacillus subtilis memicu jamur yang dipelajari menghasilkan senyawa baru dengan sifat antibakteri yang tidak ada pada kultur tunggal jamur tersebut. 


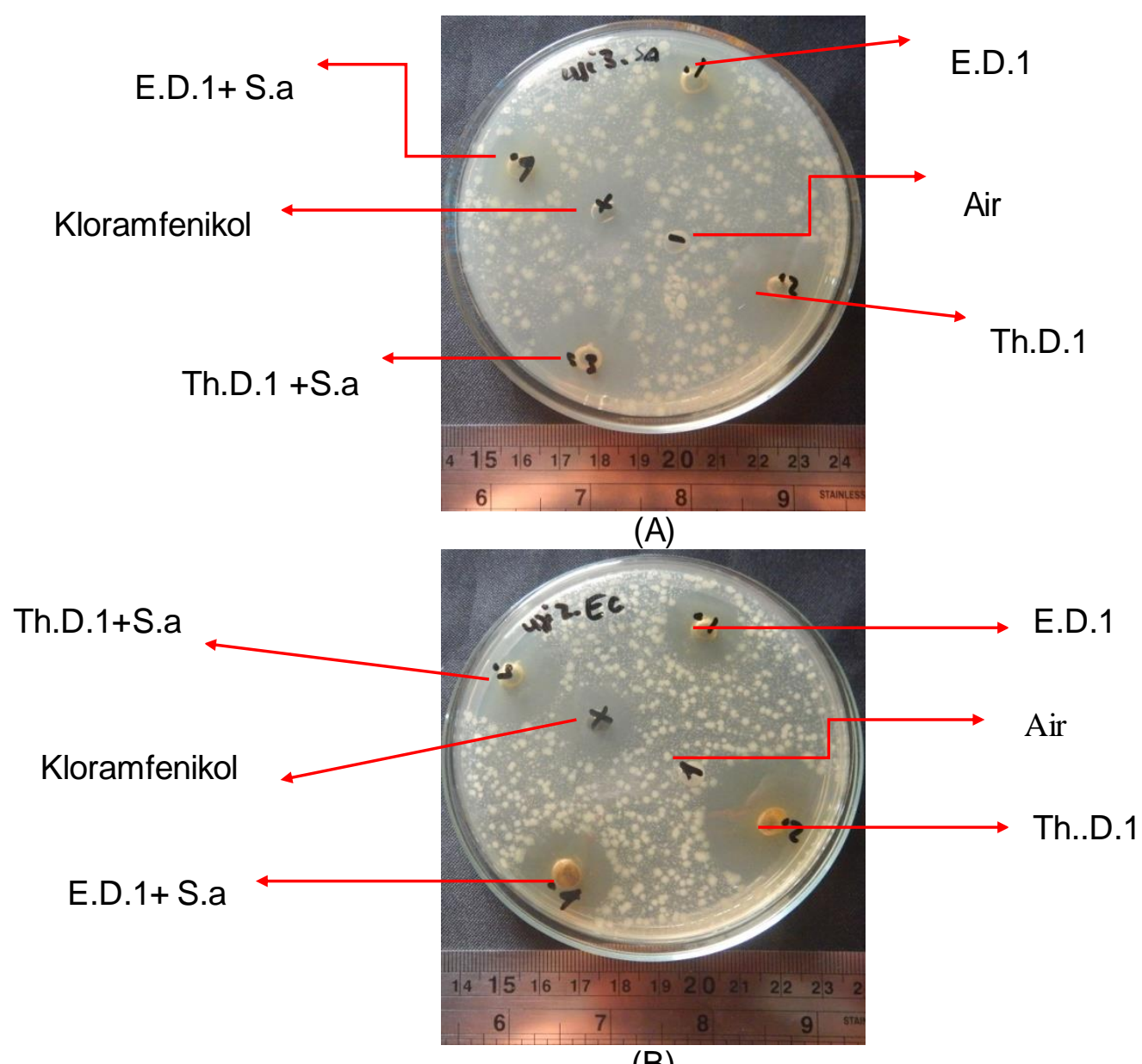

(B)

Gambar 3. Uji ekstrak jamur pada: bakteri S. aureus (A) dan E. coli (B).

Tabel 2. Pengukuran diameter zona hambat ekstrak jamur terhadap baketeri

\begin{tabular}{llcccccccc}
\hline & & \multicolumn{4}{c}{$\begin{array}{c}\text { E. coli } \\
(\mathrm{mm})\end{array}$} & \multicolumn{4}{c}{$\begin{array}{c}\text { S. aureus } \\
\text { Node isolat jamur }\end{array}$} \\
\cline { 2 - 10 } & 1 & 2 & 3 & Rata-rata & 1 & 2 & 3 & Rata-rata \\
\hline 1 & E.D.1 & 14 & 11 & 16 & $13.7 \pm 2.5$ & 13 & 17 & 12 & $14 \pm 2.4$ \\
2 & Th.D.1 & 21 & 31 & 26 & $26 \pm 5$ & 25 & 24 & 22 & $23.7 \pm 1.5$ \\
3 & Th.D.1 + S.a & 13 & 21 & 20 & $18 \pm 4.4$ & 16 & 18 & 22 & $18.7 \pm 3.1$ \\
4 & E.D.1 + S.a & 15 & 18 & 12 & $15 \pm 3.0$ & 19 & 15 & 11 & $15 \pm 4.0$ \\
5 & $\begin{array}{l}\text { Kontrol+ } \\
\text { (kloramfenikol) }\end{array}$ & 16 & 16 & 17 & $16.3 \pm 0.6$ & 13 & 13 & 16 & $14 \pm 1.7$ \\
\hline
\end{tabular}

\section{Partisi dan uji aktivitas antibiotik}

Partisi dilakukan untuk melihat pada fraksi mana pada ektrak jamur yang memberikan aktivitas zona hambat pada bakteri uji $S$. aureus dan E. coli. Dari tahapan fraksinasi ini didapatkan tiga hasil dari fraksinasi yaitu fraksi air, fraksi etanol dan fraksi n-heksan seperti yang disajikan pada 


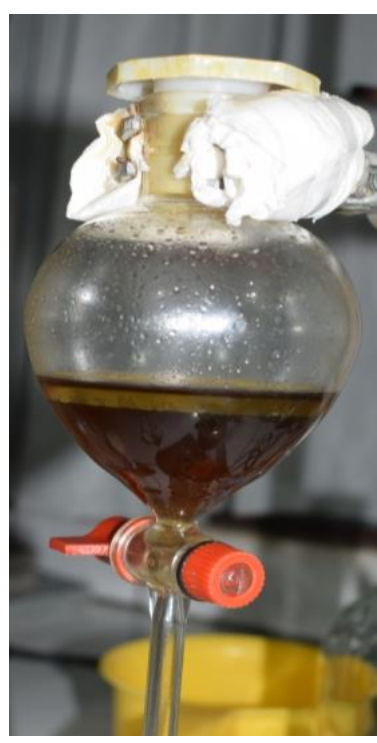

(A)

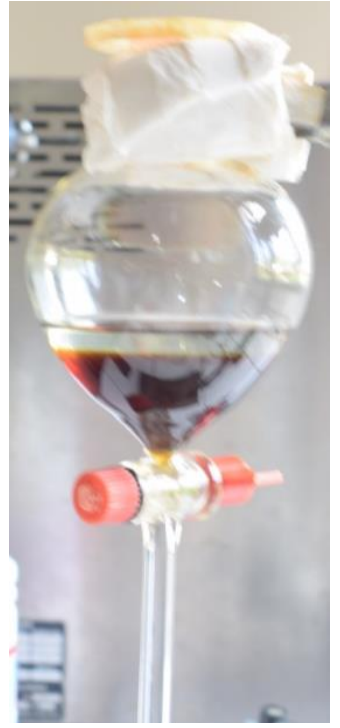

(B)

Gambar 4. Proses partisi ektrak jamur. A. fraksi etil asetat dan air ; B. fraksi n-heksan dan etanol.

Tabel 3. Pengukuran daya hambat jamur pada fraksi ekstrak jamur Th.D.1 terhadap bakteri $S$. aureus dan E. coli

\begin{tabular}{|c|c|c|c|c|c|c|c|c|}
\hline \multirow[t]{2}{*}{ Th. D. 1} & \multicolumn{4}{|c|}{$\begin{array}{c}\text { S. aureus } \\
(\mathrm{mm})\end{array}$} & \multicolumn{4}{|c|}{$\begin{array}{l}\text { E. coli } \\
(\mathrm{mm})\end{array}$} \\
\hline & 1 & 2 & 3 & Rata-rata & 1 & 2 & 3 & Rata-rata \\
\hline Fraksi air & 13 & 14 & 13 & $13.3 \pm 0.6$ & 20 & 18 & 17 & $18.3 \pm 1.5$ \\
\hline Fraksi etanol & 21 & 19 & 19 & $19.7 \pm 1.2$ & 28 & 30 & 29 & $29 \pm 1.0$ \\
\hline Fraksi n-heksan & 0 & 0 & 0 & 0 & 0 & 0 & 0 & 0 \\
\hline Kontrol negative & 0 & 0 & 0 & 0 & 0 & 0 & 0 & 0 \\
\hline Antibiotik (kloramfenikol) & 16 & 15 & 18 & $16.3 \pm 1.3$ & 25 & 28 & 25 & $26 \pm 1.7$ \\
\hline
\end{tabular}

Gambar 4. Senyawa-senyawa polar terlarut pada fraksi air, senyawa semi polar terlarut pada fraksi etanol sedangkan senyawa-senyawa yang sifatnya non polar terlarut terdapat pada fraksi n-heksan.

Ketiga fraksi yang telah didapatkan diuji aktivitas antibakterinya kembali untuk melihat pada fraksi mana yang mengandung senyawa yang bertanggung jawab terhadap aktivitas antibakteri pada kedua ekstrak terhadap bakteri uji $S$. aureus dan E.coli.
Gambar 5 memperlihatkan adanya zona hambat pada fraksi air dan etanol isolat jamur Th.D.1. Hasil pengukuran diameter zona hambat fraksi isolat jamur Th.D.1 terhadap bakteri $S$. aureus dan $E$. coli dapat dilihat pada Tabel 3. Hasil pengamatan fraksi ekstrak jamur Th.D.1 memperlihatkan aktivitas antibakteri terdapat pada fraksi etanol dan air.

Hal ini menunjukkan senyawa antibakteri yang terkandung pada ekstrak jamur Th.D.1 bersifat polar dan semi polar. Tidak terdapatnya aktivitas 


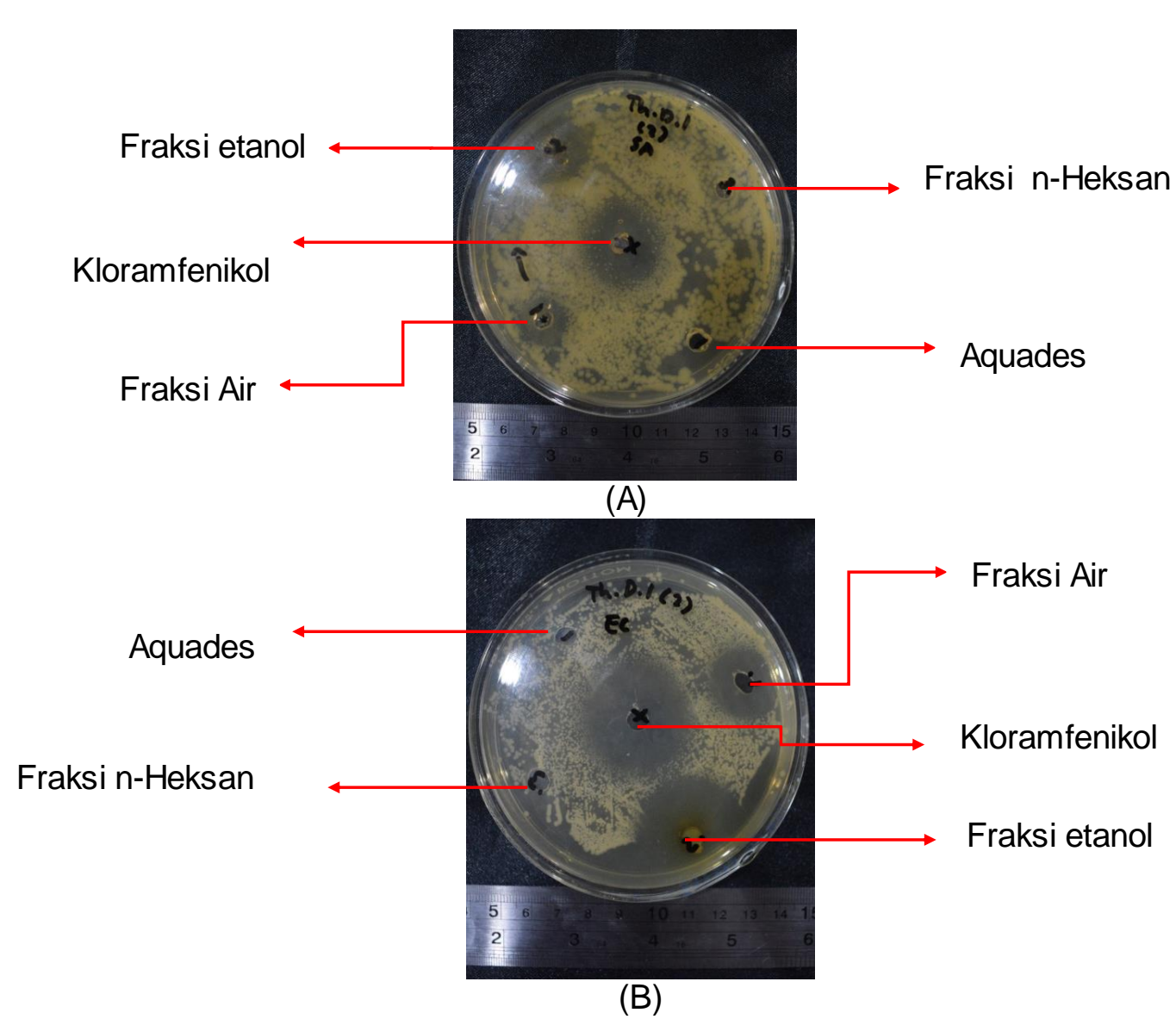

Gambar 5. Aktivitas antibakteri fraksi ekstrak Th.D.1 terhadap bakteri S. aureus (A) dan E. coli (B).

antibakteri pada fraksi $n$-heksan menunjukan bahwa senyawa antibakteri dari ekstrak jamur Th.D.1 bukan merupakan senyawa non polar.

$\mathrm{Hal}$ ini berbeda dengan penelitian Nawea dkk (2017) yang mengisolasi jamur endofit asal mangrove Sonneratia alba dan Sihombing dkk (2017) yang mengisolasi jamur simbion asal sponge Plakortis sp. Kedua jamur yang diisolasi dari organisme berbeda hanya memiliki senyawa antibakteri yang bersifat semi polar.

Gambar 6 memperlihatkan adanya zona hambat pada fraksi air dan fraksi etanol isolat jamur E.D.1. Hasil pengujian aktivitas antibakteri fraksi ekstrak E.D.1 terhadap bakteri $S$. aureus dan $E$. coli dapat dilihat pada Tabel 4. Hal ini sesuai dengan Zulfa (2016) dalam penelitiannya dimana fraksi air dan fraksi etanol dari isolat jamur endofit pada akar tanaman kayu jawa yang memberikan aktivas antibakteri pada bakteri $S$. aureus dan E. coli.

Hasil penelitian pada isolat ini menunjukkan bahwa hanya pada fraksi n-heksan saja yang tidak memperlihatkan adanya zona hambat. Nilai rata-rata pengukuran diameter zona hambat yang diperoleh dari fraksi etanol isolat jamur E.D.1 adalah 12.7 $\mathrm{mm}$ terhadap bakteri $S$. aureus dan 12 $\mathrm{mm}$ terhadap bakteri $E$. coli. Sedangkan nilai pengukuran diameter zona pada fraksi air isolat jamur E.D.1 adalah $11 \mathrm{~mm}$ untuk bakteri $S$. aureus dan 10 untuk bakteri E. coli. Fraksi etanol dari isolat jamur E.D.1 menunjukan aktivitas daya hambat yang lebih besar dibandingkan dengan fraksi air. Hal ini menunjukan bahwa senyawa aktif antibakteri dari jamur endofit asal lamun $T$. hemprichi dan $E$. acoroides merupakan senyawa yang bersifat polar dan semi polar. 


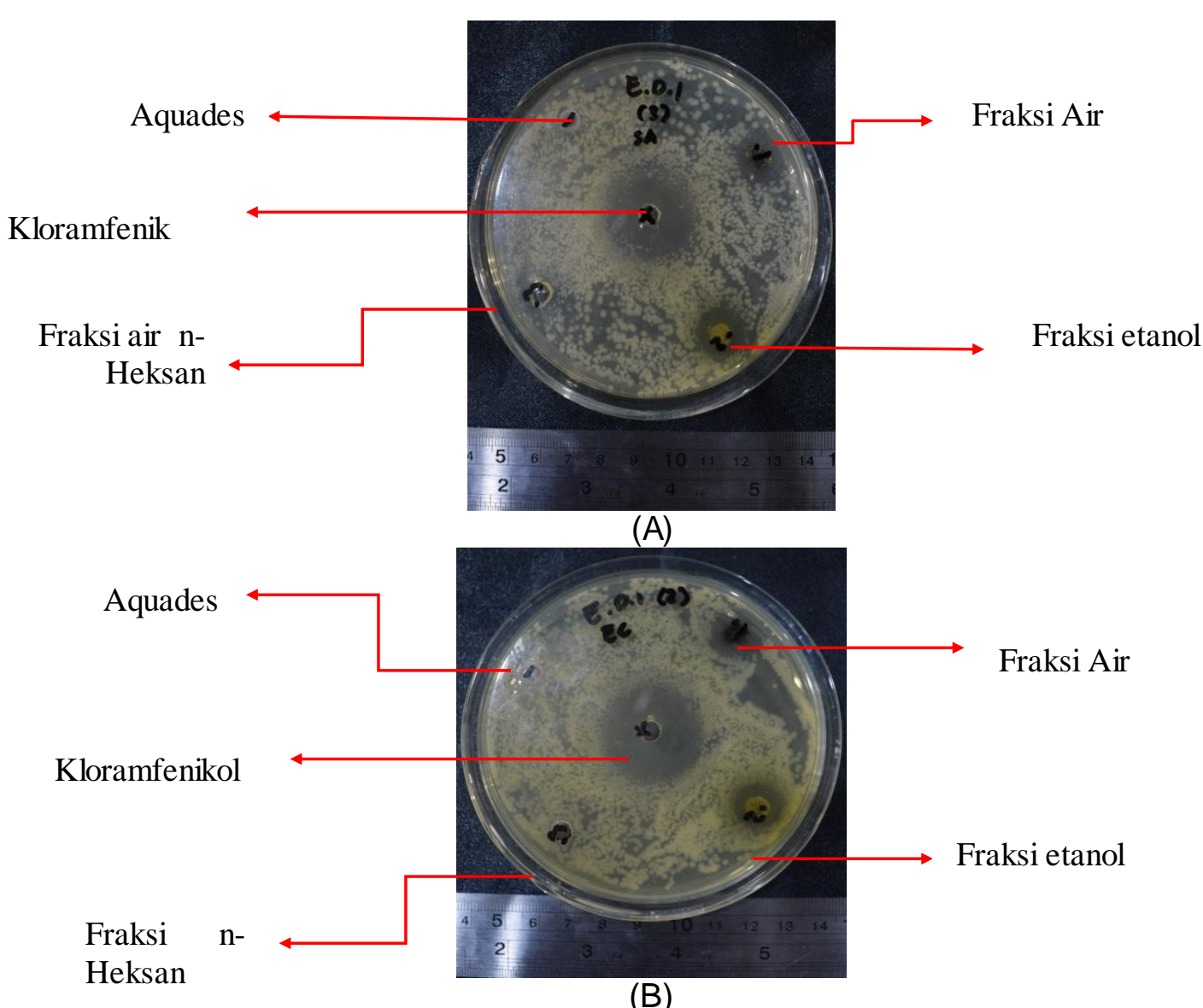

Gambar 6. Hasil pengujian aktivitas antibakteri fraksi ektrak E.D.1 terhadap bakteri S.aureus (A) dan bakteri E. coli (B).

Tabel 4. Pengukuran daya hambat jamur pada fraksi ektrak jamur E.D.1 pada bakteri $S$. aureus dan E. coli.

\begin{tabular}{|c|c|c|c|c|c|c|c|c|}
\hline \multirow{2}{*}{ E. D. 1} & \multicolumn{4}{|c|}{$\begin{array}{c}\text { S. aureus } \\
(\mathrm{mm})\end{array}$} & \multicolumn{4}{|c|}{$\begin{array}{l}\text { E. coli } \\
(\mathrm{mm})\end{array}$} \\
\hline & 1 & 2 & 3 & $\begin{array}{c}\text { Rata- } \\
\text { rata }\end{array}$ & 1 & 2 & 3 & $\begin{array}{l}\text { Rata- } \\
\text { rata }\end{array}$ \\
\hline Fraksi air & 10 & 10 & 13 & $11 \pm 1.7$ & 0 & 15 & 15 & $10 \pm 8.7$ \\
\hline Fraksi etanol & 12 & 12 & 14 & $12.7 \pm 1.2$ & 11 & 12 & 13 & $12 \pm 1.0$ \\
\hline Fraksi n-heksan & 0 & 0 & 0 & 0 & 0 & 0 & 0 & 0 \\
\hline Kontrol negative & 0 & 0 & 0 & 0 & 0 & 0 & 0 & 0 \\
\hline $\begin{array}{l}\text { Antibiotik } \\
\text { (kloramfenikol) }\end{array}$ & 15 & 15 & 20 & $16.7 \pm 2.9$ & 22 & 26 & 25 & $24.3 \pm 2.1$ \\
\hline
\end{tabular}

Untuk mengetahui apakah senyawa yang dihasilkan dari isolat jamur E.D.1 dan Th.D.1 memiliki keasamaan atau tidak. Karena jamur yang dihasilkan dari daun $T$. hemprichi dan E. acoroides memiliki kesamaan karakteristik, maka fraksi yang memiliki aktivitas antibakteri dilajutkan dengan pengamatan spektrum senyawa menggunakan spektofotometer UV-Vis. 
Fraksi air dari kedua isolat jamur yang berbeda di bandingkan.

Pada fraksi air (Gambar 7) dari kedua isolat menunjukan perbedaan. Di mana serapan maksimum isolat jamur E.D.1 terdapat pada panjang gelombang $200 \mathrm{~nm}, 280 \mathrm{~nm}$, dan 420 $\mathrm{nm}$, sedangkan pada isolat jamur
Th.D.1 memperlihatkan serapan maksimum pada panjang gelombang $220 \mathrm{~nm}, 250 \mathrm{~nm}$, dan $380 \mathrm{~nm}$. Hal ini menunjukkan senyawa antibakteri dari fraksi air pada isolat jamur E.D.1 berbeda dengan senyawa antibakteri pada isolat jamur Th.D.1.

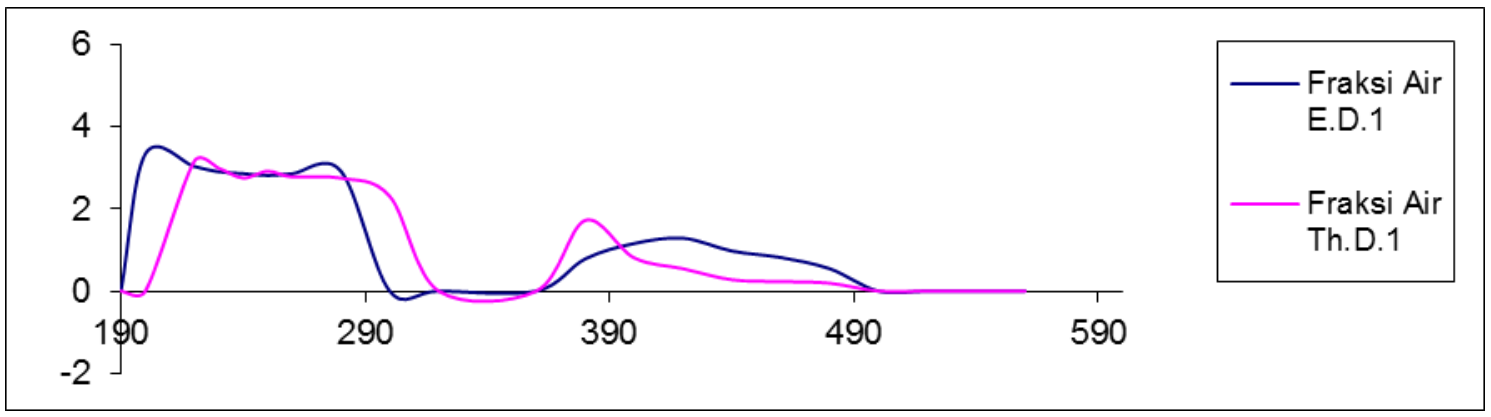

Gambar 7. Grafik perbedaan serapan optik fraksi air.

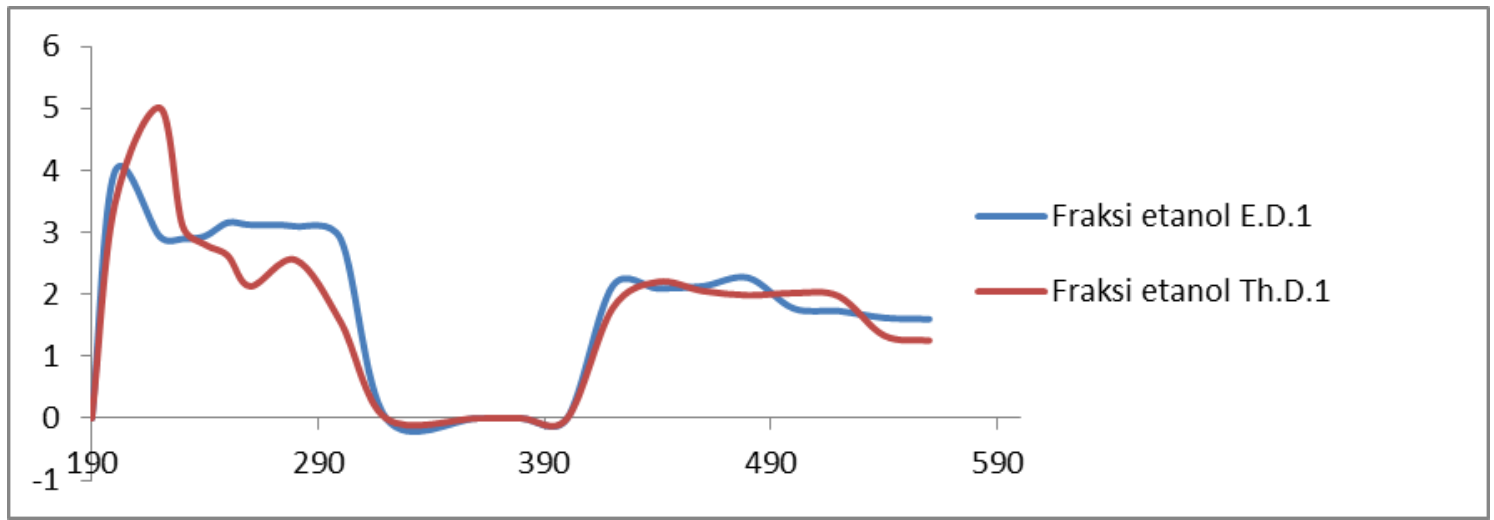

Gambar 8. Grafik perbedaan serapan optik fraksi etanol

Perbandingan selanjutnya pada fraksi etanol dari kedua isolat jamur E.D.1 dan Th.D.1 (Gambar 8). Jumlah serapan maksimum fraksi metanol isolat jamur E.D.1 memperlihatkan pada panjang gelombang $200 \mathrm{~nm}, 250$ $\mathrm{nm}, 420 \mathrm{~nm}$, dan $480 \mathrm{~nm}$, sedangkan untuk serapan maksimum isolat jamur Th.D.1 terjadi pada panjang gelombang $220 \mathrm{~nm}, 280 \mathrm{~nm}, 420 \mathrm{~nm}$ dan $440 \mathrm{~nm}$. Hal ini menunjukan bahwa senyawa antibakteri fraksi etanol dari isolat jamur E.D.1 dan Th.D.1 merupakan senyawa yang berbeda.

\section{KESIMPULAN}

a. Pengujian awal dari sepuluh isolat menunjukkan hanya dua isolat jamur endofit dari daun Thalassia hemprichii dan daun Enhalus acoroides yang memiliki aktivitas terhadap bakteri $S$. aureus dan $E$. coli. ;

b. Induksi bakteri $S$. aureus pada kedua isolat jamur endofit tidak memberikan pengaruh terhadap aktivitas antibakteri. 
c. Aktivitas antibakakteri fraksi etanol dari ekstrak daun Thalassia hemprichii dapat menyamai antibiotik Chloramphenicol terhadap bakteri $S$. aureus dan $E$. coli.

d. Hasil spektrofotometri menunjukan bahwa kedua senyawa antibakteri dari isolat Th.D.1 dan E.D.1 merupakan senyawa yang berbeda.

\section{DAFTAR PUSTAKA}

Bara, R., Amal, H., Wray, V., Lin, W., Proksch, P., Debbab, A. 2013. Talaromins A and B, New cyclic Peptides from The Endophytic Fungus Talaromyces worimannii. Tetrahedron Letters, 54: 1686-1689.

Bara, R. A., Zerfass. I., Daowan, L., Weihan, L., Brötz-Oesterelt, H., Porksch, P. 2013. New Natural Product from Botryosphaeria australis, an Endophyte from Mangrove Avicennia marina. Squalen Bulletin of Marine \& Fhiseries Postharvest.\& Biotechnology. 8(3): 139-145.

Fusetani, N. 2000. Drug from Sea. 107. Karger. Tokyo.

Nawea, Y., Mangindaan, R., Bara, R. 2017. Uji Antibakteri Jamur Endofit Dari Tumbuhan Mangrove Soneratia alba yang Tumbuh di Perairan Pantai Tanahwangko. Jurnal Pesisir dan Laut Tropis. I: 24-35.

Nontji, A. 2005. Laut Nusantara. Cetakan Keempat. Djambatan. Jakarta.

Nuriah, A. A. A. 2014. Aktivitas Antijamur Bakteri Endofit Lamun Terhadap Jamur Patogen. Skripsi Program Studi IImu Kelautan, Fakultas Perikanan dan IImu Kelautan. UNDIP Semerang.
Ola, A. R. B., Thomy, D., Lai, D., Brotz-Oesterhelt. H., Prolcsch, P. 2013. Inducing secondary metabolite production by the endophytic fungus Fusarium trinctum trought coculture with Bacillus subtilis. J. Nat. Prod. 76: 2094-2099.

Sihombing, F., Bara, R. A., Fitje, L. 2017. Skrining Aktivitas Antibiotik Jamur Simbion Pada Spons di Perairan Malalayang. Jurnal Pesisir dan Laut Tropis. I: 1-8.

Strobel, G., Daisy, B., U. Castillo., J. Harper 2003. Bioprospecting for Microbial Endophytes and Their Natural Products. Microbiology and Molecular Biology Reviews. 67(4): 491-502.

Zulfa, I. 2016. Isolasi dan Uji Aktivitas Antibakteri Kapang Endofit Akar Tanaman Kayu Jawa (Lennea coromandelica (Houtt)Merr.). Skripsi. Program Studi Farmasi. Fakultas Kedoketran dan IImu Kesehatan. UIN Syarif Hidayatullah Jakarta. 